\title{
Effect of pre-wintering and wintering temperature regimes on weight loss, survival, and emergence time in the mason bee Osmia cornuta (Hymenoptera: Megachilidae)
}

\author{
Jordi BosCH ${ }^{\mathrm{a} *}$, William P. KEMP $\mathrm{P}^{\mathrm{b}}$ \\ a Biology Department, Utah State University, Logan, UT 84322-5310, USA \\ ${ }^{\mathrm{b}}$ USDA-Agricultural Research Service, Bee Biology and Systematics Laboratory, Logan, UT 84322-5310, USA
}

(Received 9 July 2003; revised 26 November 2003; accepted 4 January 2004)

\begin{abstract}
Osmia cornuta adults require exposure to wintering temperatures followed by incubation in the spring to emerge. We studied winter survival, weight loss, emergence time, and post-emergence longevity in $O$. cornuta exposed to a variety of pre-wintering and wintering treatments. Few bees emerged after exposure to wintering durations $<30$ days. Maximum survival and longevity were obtained with wintering durations of 90-150 days. Time to emergence following incubation declined with increasing wintering duration and increasing wintering temperature. Pre-wintering treatment had a dramatic effect on bee fitness. Bees pre-wintered for 15 days lost less weight, had higher survival and lived longer than bees pre-wintered for 45 or 75 days. In general, larger bees were more likely to survive the winter and lived longer than smaller bees. We discuss the relevance of these results to survival in wild $O$. cornuta populations and the management of populations used in orchard pollination.
\end{abstract}

Osmia cornuta / wintering temperature / body weight / orchard pollination

\section{INTRODUCTION}

Osmia cornuta (Latreille) is a solitary, univoltine, spring-flying mason bee distributed throughout most of central and southern Europe and parts of the Middle East (Peters, 1977). Adult females are active for approximately 20 days in the spring, during which time they build one or more nests in abandoned beetle burrows in dead timber or vacant nests of other bees (mainly Anthophora) in clay embankments. In addition to foraging for pollen and nectar to provision their nests, females also collect mud to build cell partitions and to seal completed nests. Eggs hatch in approximately one week, immature development pro- ceeds through the spring-summer period, and adulthood occurs in late-summer or early autumn. Eclosed adults remain in their cocoons through the winter, and emerge the next spring as temperatures rise. Respirometry studies with the closely-related species Osmia lignaria Say (Kemp et al., 2004) indicate that this winter dormancy is diapause-mediated (sensu Tauber et al., 1986). Wintering in the adult stage appears to be a derived trait within the family Megachilidae and the genus Osmia (Bosch et al., 2001), and is probably associated with the early seasonal activity period of $O$. cornuta. Most other Megachilidae winter as prepupae and adults are active later in the year (Bosch et al., 2001).

\footnotetext{
* Corresponding author: Jordi.Bosch@uab.es

Present address: Unitat d'Ecologia, Facultat de Ciències, Universitat Autònoma de Barcelona, 08193 Bellaterra, Spain.
} 
Osmia cornuta is an excellent pollinator of fruit trees, and has been studied as an orchard pollinator in several countries (Asensio, 1984; Torchio et al., 1987; Krunic et al., 1991; Bosch, 1994a; Maccagnani et al., 2003). As a result, its foraging and nesting behavior are relatively well known (Taséi, 1973a; Maddocks and Paulus, 1987; Jacob-Rémacle, 1990; Bosch, 1994b; Bosch and Blas, 1994a; Vicens and Bosch, 2000a), and methods to manage $O$. cornuta populations have been developed, including preferred nesting materials and nesting cavity sizes, releasing methods, and number of bees required per orchard area (Bosch, 1994b, c, 1995; Vicens and Bosch, 2000b). There is, however, much less information available on the developmental biology and wintering requirements of $O$. cornuta populations (Taséi, 1973b; Bosch and Blas, 1994b). Previous studies indicate that winter survival in $O$. cornuta from NE Spain is high $(>95 \%)$ when bees are artificially wintered $\left(3-5^{\circ} \mathrm{C}\right)$ for a period of 100-120 days, beginning in October to earlyNovember (Bosch, 1994a; Bosch and Blas, 1994b). Populations artificially wintered later in the year (late-November) for shorter periods (75 days) have lower winter survival $(<86 \%)$ (Bosch, 1994a, 1995). Some bees from the latter populations actually survive the winter, but are not vigorous enough to chew their way out of their cocoons the following spring (Bosch, 1994a). These results suggest a strong effect of pre-wintering periods (defined as the period from adult eclosion to initiation of wintering) and/or wintering periods (period from initiation of wintering to spring incubation) on $O$. cornuta survival and vigor. Previous studies also demonstrate a strong effect of wintering periods on emergence time. Bees wintered for 75 days have protracted emergence periods following spring incubation (exposure to warm temperatures that elicit emergence) compared with bees wintered for longer periods (Bosch and Blas, 1994b). To our knowledge, there is no information available on the effect of different wintering temperatures on emergence in this species.

The objective of this study was to investigate the effect of pre-wintering and wintering duration and temperature on $O$. cornuta survival, emergence time, weight loss, and vigor. Because $O$. cornuta exhibits considerable variation in body size within each sex (Bosch and Vicens,
2002), we were also interested in establishing whether large individuals were more likely to survive the winter than smaller individuals. This information is needed to establish adequate artificial rearing methods for this valuable pollinator. Small O. cornuta populations are currently used in parts of Spain, France and Serbia on commercial almonds and apples (Bosch and Kemp, 2002). The onset of declining temperatures in late summer or early autumn, and the onset of increasing temperatures in late winter or early spring vary widely among years and nesting areas. Thus, the information gained in this study is also relevant to improving our understanding of the phenology and population dynamics of wild $O$. cornuta populations.

\section{MATERIALS AND METHODS}

\subsection{Populations and rearing methods}

Bees used in this study were obtained from nesttraps placed in La Garrotxa (Girona, NE Spain) in 1993. Each nest-trap consisted of a solid wood block with 25 drilled holes, and a paper straw (length: $15 \mathrm{~cm}$; diameter: $8 \mathrm{~mm}$ ) inserted in each hole (Bosch, 1995). Osmia cornuta fly in March-April in La Garrotxa. Once a week throughout the nesting period, newly completed (plugged) nests were brought to the laboratory, where they were incubated at 20 $25^{\circ} \mathrm{C}$. After bees reached adulthood (late August), paper straws were dissected. Cocoons were then sexed according to their size and position within the nest (Bosch, 1994b). For each bee, assigned sex was confirmed at the end of the study (among other distinctive morphological characters, males have abundant white pilosity on the clypeus).

\subsection{Experiment 1 (wintering duration)}

This experiment tested the effect of wintering duration on $O$. cornuta survival, emergence time, and longevity. Nine groups of bees ( 30 female and 50 male randomly- selected cocoons per group) were wintered at $3{ }^{\circ} \mathrm{C}$ on 1 November for $1,14,30,44,64$, $94,124,154$, and 184 days, respectively. After wintering, cocoons were individually placed in glass vials at $20^{\circ} \mathrm{C}$ (spring incubation) and checked daily. Emergence and death dates were recorded, and the difference between these dates (longevity without feeding) was used as an indicator of vigor (Bosch and Kemp, 2000). All bees were weighed within their cocoons (without fecal particles) on 1 November (prior to wintering). In $O$. cornuta, cocoon weight 
Table I. Wintering duration (in days) for the nine treatments of Experiment 3. Pre-wintering durations are $\sim 15$ days, $\sim 45$ days, and $\sim 75$ days, for bees wintered on 15 September, 15 October, and 14 November, respectively.

\begin{tabular}{lccc}
\hline Wintering & \multicolumn{3}{c}{ Wintering termination } \\
\cline { 2 - 4 } initiation & 3 February & 5 March & 4 April \\
\hline 15 September & 141 & 171 & 201 \\
15 October & 111 & 141 & 171 \\
14 November & 81 & 111 & 141 \\
\hline
\end{tabular}

and adult body weight are highly correlated in both sexes $\left(r^{2} \geq 0.73, P<0.001\right)$ (Bosch and Vicens, 2002).

\subsection{Experiment 2 (wintering temperature)}

This experiment tested the effect of different wintering temperatures on bee survival, emergence time, and longevity. Six groups of bees (30 female and 50 male randomly- selected cocoons per group) were wintered for 90 days starting on 1 November at different temperatures: $-1,0.5,3,5,7$ and $11^{\circ} \mathrm{C}$. After wintering, cocoons were individually placed in glass vials at $20^{\circ} \mathrm{C}$ and checked daily to record emergence and death. As in experiment 1 , all bees were weighed within their cocoons on 1 November.

\subsection{Experiment 3 (pre-wintering and wintering duration)}

This experiment tested the combined effect of pre-wintering and wintering duration on survival, emergence time, and longevity. Nine groups of bees (30 female and 50 male randomly-selected cocoons per group) were exposed to 9 treatments that combined 3 wintering initiation dates (15 September, 15 October, and 14 November) and 3 wintering termination dates (3 February, 5 March, and 4 April), thus covering a range of pre-wintering periods from $\sim 15$ to $\sim 75$ days (bees reached adulthood in late August), and a range of wintering periods (at $3{ }^{\circ} \mathrm{C}$ ) from 81 to 201 days (Tab. I). Treatment notation for this experiment indicates the date of wintering initiation followed by the date of wintering termination. For example, bees of treatment 15 Sept.-3 Feb. were wintered from 15 September until 3 February. After wintering, bees were incubated at $20^{\circ} \mathrm{C}$, and emergence and longevity were monitored as in experiments 1 and 2. To monitor weight loss during the pre-wintering and wintering periods, bees from all treatments starting wintering on 15 October or 14 November were weighed inside their cocoons on 15 October, at the beginning of wintering, and at the end of wintering.

\subsection{Data analysis}

Statistical analyses were conducted separately for males and females. Previous studies on O. cornuta and the closely-related $O$. lignaria established that males are smaller, emerge sooner and usually live longer (without feeding) than females (Bosch and Blas, 1994b; Bosch and Kemp, 2000; Bosch and Vicens, 2002). Binary LOGIT models (PROC LOGISTIC; SAS Institute Inc., 1999; Allison, 1999) were used to test for the effect of wintering duration (experiment 1), wintering temperature (experiment 2), and pre-wintering/wintering duration (experiment 3 ), on the likelihood of survival. In experiments 1 and 2, individual weight was used as a covariate. For those individuals surviving to emergence, ANCOVA(PROC GLM; SAS Institute Inc., 1999) was used to test for the effects of wintering duration (experiment 1 ), and wintering temperature (experiment 2), on emergence time and longevity, with individual body weight as a covariate. In experiment 3, ANOVA (PROC GLM; SAS Institute Inc., 1999) was used to test the effect of pre-wintering/wintering duration on emergence time, longevity, and percent weight loss (arcsin-transformed) in those individuals that survived to emerge.

\section{RESULTS}

\subsection{Experiment 1 (wintering duration)}

The effect of wintering duration on winter survival is shown in Figure 1. Very few bees emerged following wintering periods less than 30 days. Survival increased sharply when bees were wintered for 30 days or more (Fig. 1, Tab. II), but survival remained lower than $70 \%$ in this experiment. The effect of body weight on survival was significant for both sexes, with larger individuals being more likely to survive the winter than smaller individuals (Tab. II). For those individuals that successfully emerged, emergence time decreased with wintering duration (Fig. 1, Tab. II). Emergence time decreased rapidly for wintering durations ranging from 30 to 94 days, and then more slowly for longer wintering durations. For the longest wintering tested (184 days), mean female emergence time was as short as 4.6 days, and female emergence period (time between first 

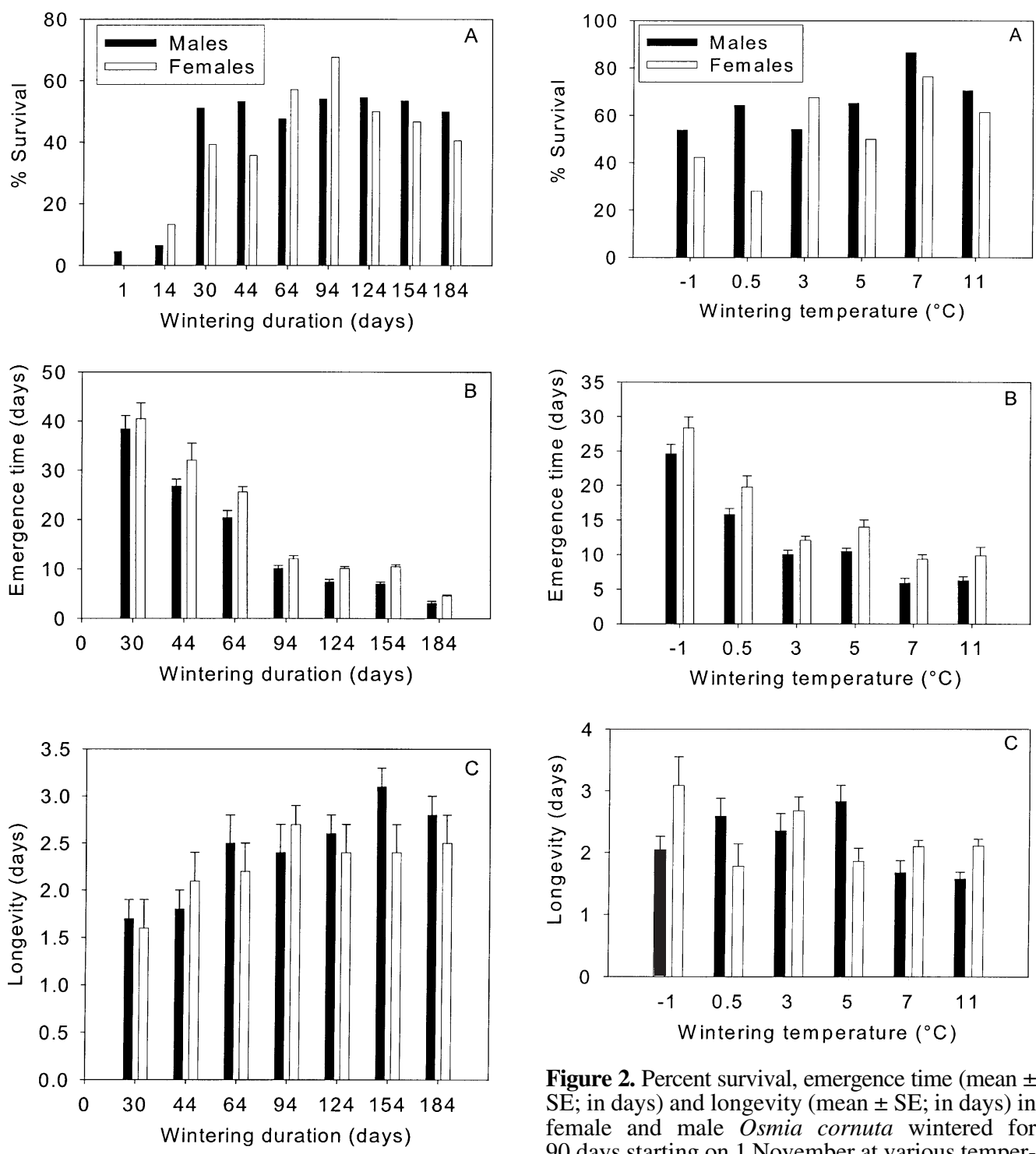

Figure 2. Percent survival, emergence time (mean \pm $\mathrm{SE}$; in days) and longevity (mean $\pm \mathrm{SE}$; in days) in female and male Osmia cornuta wintered for 90 days starting on 1 November at various temper-

Figure 1. Percent survival, emergence time (mean $\pm \mathrm{SE}$; in days) and longevity (mean $\pm \mathrm{SE}$; in days) in female and male Osmia cornuta wintered on 1 November for various durations (in days).

and last female emergence) was only 4 days. Individual body weight had no effect on emergence time (Tab. II). Longevity without feeding at $20^{\circ} \mathrm{C}$ increased with wintering duration in males but not in females (Fig. 1) (Tab. II), and larger individuals of both sexes lived longer (Tab. II).

\subsection{Experiment 2 (wintering temperature)}

Maximum survival was obtained at $7{ }^{\circ} \mathrm{C}$ in both sexes (Fig. 2). The effect of wintering temperature on survival was significant for females, but failed significance for males (Fig. 2, 
Table II. Analysis summaries for LOGIT and ANCOVA models assessing the effect of wintering duration and body weight on survival, emergence time and longevity in female and male Osmia cornuta.

\begin{tabular}{|c|c|c|c|c|c|c|}
\hline \multirow[b]{3}{*}{ Effect } & \multicolumn{3}{|c|}{ Females } & \multicolumn{3}{|c|}{ Males } \\
\hline & \multicolumn{6}{|c|}{ Survival } \\
\hline & df & Wald $\chi^{2}$ & $P$ & df & Wald $\chi^{2}$ & $P$ \\
\hline Wintering duration & 8 & 22.49 & 0.004 & 8 & 41.38 & $<0.0001$ \\
\hline \multirow[t]{2}{*}{ Body weight } & 1 & 7.82 & 0.005 & 1 & 21.31 & $<0.0001$ \\
\hline & \multicolumn{6}{|c|}{ Emergence time } \\
\hline Effect & $\mathrm{df}$ & $F$ & $P$ & $\mathrm{df}$ & $F$ & $P$ \\
\hline Wintering duration & 7 & 83.95 & $<0.0001$ & 7 & 86.86 & $<0.0001$ \\
\hline \multirow[t]{2}{*}{ Body weight } & 1 & 0.00 & 0.95 & 1 & 0.42 & 0.52 \\
\hline & \multicolumn{6}{|c|}{ Longevity } \\
\hline Effect & df & $F$ & $P$ & df & $F$ & $P$ \\
\hline Wintering duration & 7 & 1.32 & 0.25 & 7 & 5.31 & $<0.0001$ \\
\hline Body weight & 1 & 5.28 & 0.03 & 1 & 14.26 & 0.0002 \\
\hline
\end{tabular}

Table III. Analysis summaries for LOGIT and ANCOVA models assessing the effect of wintering temperature and body weight on survival, emergence time and longevity in female and male Osmia cornuta.

\begin{tabular}{|c|c|c|c|c|c|c|}
\hline \multirow[b]{3}{*}{ Effect } & \multicolumn{3}{|c|}{ Females } & \multicolumn{3}{|c|}{ Males } \\
\hline & \multicolumn{6}{|c|}{ Survival } \\
\hline & $\mathrm{df}$ & Wald $\chi^{2}$ & $P$ & df & Wald $\chi^{2}$ & $P$ \\
\hline Wintering temperature & 5 & 20.52 & 0.001 & 5 & 10.81 & 0.06 \\
\hline \multirow[t]{2}{*}{ Body weight } & 1 & 1.32 & 0.25 & 1 & 3.97 & 0.05 \\
\hline & \multicolumn{6}{|c|}{ Emergence time } \\
\hline Effect & df & $F$ & $P$ & df & $F$ & $P$ \\
\hline Wintering temperature & 5 & 40.25 & $<0.0001$ & 5 & 77.34 & $<0.0001$ \\
\hline \multirow[t]{2}{*}{ Body weight } & 1 & 1.05 & 0.31 & 1 & 0.79 & 0.38 \\
\hline & \multicolumn{6}{|c|}{ Longevity } \\
\hline Effect & df & $F$ & $P$ & df & $F$ & $P$ \\
\hline Wintering temperature & 5 & 3.56 & 0.005 & 5 & 5.95 & $<0.0001$ \\
\hline Body weight & 1 & 0.65 & 0.43 & 1 & 6.74 & 0.01 \\
\hline
\end{tabular}

Tab. III). Body weight only had a marginal effect on male survival (Tab. III). Emergence time decreased with increasing temperatures (Fig. 2, Tab. III), and at $11^{\circ} \mathrm{C}$, two males emerged during wintering (prior to incubation at $20^{\circ} \mathrm{C}$ ). Emergence time was not influenced by body size in either sex (Tab. III). The effect of wintering temperature on longevity was less clear, but bees wintered at the coldest temperatures $\left(-1\right.$ to $\left.5{ }^{\circ} \mathrm{C}\right)$ tended to live longer (Fig. 2,
Tab. III). Body size was a significant covariate only for males (Tab. III).

\subsection{Experiment 3 (pre-wintering/ wintering duration)}

Winter survival of $O$. cornuta decreased very rapidly with increasing pre-wintering duration (Fig. 3, Tab. IV). In treatments with short or intermediate pre-wintering duration 

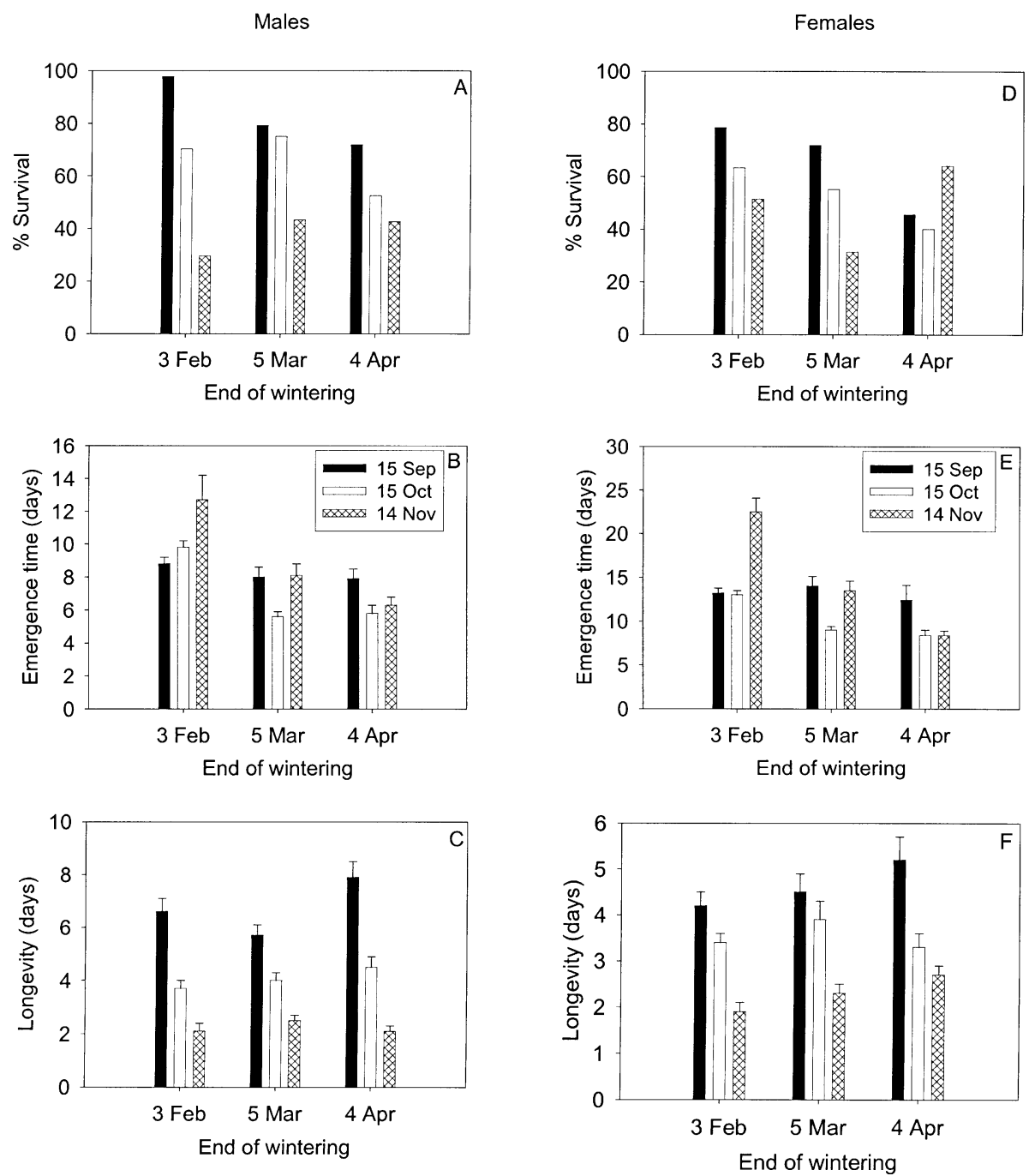

Figure 3. Percent survival, emergence time (mean \pm SE; in days) and longevity (mean \pm SE; in days) in female and male Osmia cornuta exposed to various combinations of pre-wintering and wintering durations. Pre-wintering durations are $\sim 15$ days, $\sim 45$ days, and $\sim 75$ days, for bees wintered on 15 September, 15 October, and 14 November, respectively. For wintering durations see Table I.

(15 Sept. and 15 Oct.) survival also decreased with increasing wintering duration, but at a slower rate. Survival close to $100 \%$ was only obtained when bees were pre-wintered for $\sim 15$ days and wintered for 141 days (Fig. 3 ). As in experiment 1 , emergence time decreased with increasing wintering duration (Fig. 3, Tab. IV). The effect of pre-wintering periods on emergence time was less clear, but bees prewintered for a long period and wintered for a short period (14 Nov.-3 Feb.) were very slow to emerge. On the other hand, two males of this treatment emerged before 14 November, prior to wintering. Longevity without feeding decreased rapidly with pre-wintering duration (Fig. 3, Tab. IV). Bees lost weight much more rapidly during pre-wintering than during wintering. As a result, weight losses by the end of wintering were $4-5 \%$ higher in bees pre-wintered for $\sim 75$ days ( 14 Nov.- treatments) than 
Table IV. Analysis summaries for LOGIT and ANOVA models assessing the effect of pre-wintering/wintering duration on survival, emergence time and longevity in female and male Osmia cornuta.

\begin{tabular}{cccccc}
\hline \multicolumn{5}{c}{ Females } \\
\hline \multicolumn{7}{c}{ Survival } \\
\hline df & Wald $\chi^{2}$ & $P$ & df & Wald $\chi^{2}$ & $P$ \\
8 & 21.98 & 0.005 & 8 & 51.67 & $<0.0001$ \\
\hline \multicolumn{7}{c}{ Emergence time } \\
\hline df & $F$ & $P$ & df & $F$ & $P$ \\
8 & 18.26 & $<0.0001$ & 8 & 13.86 & $<0.0001$ \\
\hline \multicolumn{7}{c}{ Longevity } \\
\hline df & $F$ & $P$ & df & $F$ & $P$ \\
8 & 9.94 & $<0.0001$ & 8 & 22.39 & $<0.0001$ \\
\hline
\end{tabular}

in bees pre-wintered for $\sim 45$ days (15 Oct.treatments) (Tab. V; Females: $F=59.44$; df $=$ 5, 86; $P<0.0001$; Males: $F=25.60 ; \mathrm{df}=5,131$, $P<0.0001)$.

\section{DISCUSSION}

Pre-wintering duration has a dramatic effect on weight loss and subsequent survival and vigor in O. cornuta. The results of experiment 3 combined with preliminary results on bees prewintered for less than 10 days (J. Bosch, unpublished) suggest that optimal pre-wintering periods for $O$. cornuta range between 10 and 30 days. This explains the poor survival registered in experiments 1 and 2, when bees were pre-wintered for 60 days, and in field populations not wintered until late November (Bosch, 1994a, 1995). Recent studies on O. lignaria have detected apparent fat body depletion in bees pre-wintered for excessively long periods (Bosch et al., 2000; Bosch and Kemp, 2001). In the tortricid Choristoneura fumiferana (Clemens), individuals exposed to extended or warm pre-wintering periods exhibited greater losses of energy reserves (triglycerides and glycogen) and expressed higher winter mortality than individuals exposed to shorter or cooler prewintering periods (Han and Bauce, 1997, 1998). Loss of energy reserves during pre-wintering is consistent with the decreased longevity observed in this study in $O$. cornuta pre-wintered for long periods. It is also consistent with observations in late-wintered populations of individuals that survived the winter, but were not vigorous enough to fly (N. Vicens and J. Bosch, unpublished), or to chew their way out of the cocoon (Bosch, 1994a).

The respirometry of $O$. lignaria, which, like $O$. cornuta, reaches adulthood in autumn and overwinters in the adult stage, has been recently studied (Kemp et al., 2004). Respiration rates in $O$. lignaria start declining immediately after adult eclosion, irrespective of temperature, and reach minimum values 2-4 weeks thereafter. If bees are then chilled, respiration rates start rising, and continue to increase steadily throughout the winter. Weight losses in chilled bees are moderate. Conversely, non-chilled adults maintain low respiration rates, express dramatic weight losses, and die during the winter (J. Bosch, W.P. Kemp, F. Sgolastra, unpublished). Thus, it appears that maximum survival in both species is obtained when wintering initiation is timed with the period of minimum respiration rates, 2-4 weeks after reaching adulthood. Individual variability in adulthood timing within a population implies that different individuals will be more or less fit to survive the winter and

Table V. Percent body weight loss (mean \pm SE) in Osmia cornuta females and males exposed to various combinations of pre-wintering and wintering durations. Pre-wintering durations are $\sim 45$ days, and $\sim 75$ days, for bees wintered on 15 October, and 14 November, respectively. For wintering durations see Table I.

\begin{tabular}{lcccc}
\hline $\begin{array}{l}\text { Wintering } \\
\text { initiation }\end{array}$ & Sex & & Wintering termination & \\
& & 3 February & 5 March & 4 April \\
\hline 15 October & o & $4.25 \pm 0.08$ & $5.99 \pm 0.11$ & $7.57 \pm 0.41$ \\
& $\sigma$ & $4.02 \pm 0.09$ & $5.66 \pm 0.16$ & $7.44 \pm 0.59$ \\
14 November & $\varnothing$ & $8.83 \pm 0.16$ & $10.14 \pm 0.24$ & $12.21 \pm 0.35$ \\
& or & $8.09 \pm 0.28$ & $9.26 \pm 0.14$ & $10.89 \pm 0.47$ \\
\hline
\end{tabular}


emerge as healthy, vigorous adults depending on the onset of "winter" temperatures in nature. In years with late-arriving winters, early-developing individuals will be exposed to long prewintering periods. In $O$. lignaria, adulthood occurrence spanned more than one month and late-developing individuals (wintered 9-16 days after adulthood), showed less evidence of fat body depletion and had longer post-emergence longevity than early-developing individuals (wintered 37-51 days after adulthood) (Bosch et al., 2000). Conversely, in years with an earlyarriving winter, individuals with slow developmental rates may have to winter as teneral adults (with reduced chances of survival; J. Bosch, W.P. Kemp, F. Sgolastra, unpublished) or even as pupae (with no chance of survival; Bosch and Kemp, 2000). Phenological variability within a population has been shown to play an important role in individual fitness in other insects. In the geometrid Epirrita autumnata Bkh., pupal period duration (and hence adult emergence time) is highly variable (1-3 mo) (Tammaru et al., 1999). Weather conditions during adult flight in this species appeared to exert only a weak selective pressure for increased variation in emergence date, but egglaying date in autumn was correlated with hatch date the next spring, which greatly affected larval performance via synchrony with host plant bud burst (Tammaru et al., 1999). High mortality in the ladybird beetle, Coccinella septempunctata L., was reported when anomalous weather conditions delayed egg-laying by firstgeneration adults, leaving insufficient time to second-generation offspring to reach the adult (wintering) stage before the onset of winter temperatures (Dobzhanski, 1921; cited in Hodek and Honek, 1996).

Like O. lignaria (Bosch and Kemp, 2003), $O$. cornuta requires a period of exposure to chilling temperatures followed by a period of warm temperatures for prompt spring emergence. The time to emerge after exposure to warm temperatures is inversely related to the duration of the cold exposure period, a pattern that has been described for numerous temperatezone winter-diapausing insects (e.g. Neilson, 1962; McLeod et al., 1985; Bell, 1989; Wang and Laing, 1989; Denlinger and Tanaka, 1999). Although in some insect species diapause may alternatively be completed without chilling (Danks, 1987; Hodek and Hodková, 1988), individuals of both Osmia species chilled for less than 90 days have low survival, protracted emergence periods and are less vigorous after emergence. In both species, however, warmer wintering temperatures $\left(7\right.$ to $13{ }^{\circ} \mathrm{C}$ ) result in faster emergence than cooler temperatures $(-1$ to $4{ }^{\circ} \mathrm{C}$ ) (Bosch and Kemp, 2003; this study). These findings agree with recent respirometry studies that show that respiration rates in O. lignaria adults increase faster when diapausing adults are exposed to $7^{\circ} \mathrm{C}$ than to $0^{\circ} \mathrm{C}$ (J. Bosch, W.P. Kemp, F. Sgolastra, unpublished). Thus, winter diapause development in both Osmia species is consistent with a dynamic model proposed by Sawyer et al. (1993), under which the thermal response of the insect progressively changes from low to high temperature optima throughout the winter.

The results of this study have a direct application to the development of rearing methods for $O$. cornuta populations used in orchard pollination. In general terms, $O$. cornuta response to wintering duration and temperature was similar to that observed in O. lignaria (Bosch and Kemp, 2003). In both species, maximum survival was obtained after 90-150 wintering days, and, at least for wintering durations $\leq 150$ days, longevity (an indicator of vigor) increased with increasing wintering duration. As mentioned, emergence time decreased with increasing wintering duration and increasing wintering temperature in both species. Post-emergence longevity also decreased with increasing temperature in both species, but maximum survival was obtained at a lower temperature $\left(0{ }^{\circ} \mathrm{C}\right)$ for O. lignaria, than for $O$. cornuta $\left(7^{\circ} \mathrm{C}\right)$. Optimal wintering temperature and duration are expected to vary not only between both species, but also between populations within a species. For example, male February-flying $O$. cornuta wintered for 90 days at $3{ }^{\circ} \mathrm{C}$ emerged in 2.1 days (Bosch and Blas, 1994b), compared to 10.1 days in the March-April-flying population of this study wintered for 94 days at $3{ }^{\circ} \mathrm{C}$. In the Februaryflying population, males started emerging at $3{ }^{\circ} \mathrm{C}$ before 120 days of wintering (Bosch and Blas, 1994b), whereas bees of this study could be wintered for up to 184 days without males emerging prematurely (before incubation).

Correct management of pre-wintering periods is essential for winter survival and vigor. Starting in late-summer, adulthood should be closely monitored, and populations should be 
wintered no later than 1-2 weeks after the last individuals have reached adulthood. Short prewintering periods will also allow for longer wintering duration, which in turn will promote faster emergence and facilitate timing with orchard bloom the following spring. Fast emergence can also be achieved by raising wintering temperatures, although at some metabolic cost in terms of weight loss, fat body depletion and associated vigor (Bosch et al., 2000; Bosch and Kemp, 2003). Body size had a significant effect on survival and longevity (except for females of experiment 2), but not on emergence time. A positive correlation between body size and winter survival was also found in $O$. lignaria (Tepedino and Torchio, 1982). These results emphasize the importance of releasing appropriate bee densities (Torchio, 1985; Bosch, 1994b; Vicens and Bosch, 2000b) in orchard operations, so as to maximize pollination without enhancing competition for floral resources, which results in reduced offspring body size (Torchio, 1985).

\section{ACKNOWLEDGMENTS}

Thanks are due to J. Calzadilla, M.A. Escolano, M. López and N. Vicens for their help in obtaining bee populations and in nest dissection. D.J. Burdick (California State University, Fresno), P.F. Torchio and G.E. Trostle (USDA-ARS, Logan) provided insight during the preparation of the study. The manuscript was improved through comments from K.M. O'Neill (Montana State University, Bozeman) and T.L. Pitts-Singer (USDA-ARS, Logan). This study was supported by a FPI fellowship from the Spanish MEC to J. Bosch.

Résumé - Effets de divers régimes de température de pré-hivernage et d'hivernage sur la perte de poids, la survie et la période d'émergence chez l'Abeille maçonne Osmia cornuta (Hymenoptera, Megachilidae). Les adultes de l'abeille solitaire univoltine Osmia cornuta (Latreille) restent dans leur cocon durant tout l'hiver après l'éclosion et ont besoin d'une exposition à des températures hivernales suivie d'une période d'incubation pour émerger au printemps. Nous avons étudié la survie hivernale, la perte de poids, la période d'émergence (après l'incubation post-hivernale) et la longévité après l'émergence (comme indice de vigueur) chez l'abeille $O$. cornuta exposée à divers régimes de températures de pré-hivernage (période entre l'éclosion de l'adulte et l'exposition aux températures hivernales) et d'hivernage (période entre l'exposi- tion aux températures hivernales et l'incubation au printemps). Les cocons renfermant les adultes ont été placés individuellement dans des récipients en verre et transférés dans des chambres thermorégulées selon chaque traitement. Peu d'abeilles ont émergé après l'exposition à un hivernage de moins de 30 jours et la survie et la longévité maximales ont été obtenues avec un hivernage compris entre 90 et 150 jours (Fig. 1). La période d'émergence était raccourcie quand la durée de l'hivernage et la température d'hivernage augmentaient (Fig. 1). La survie a eu tendance à augmenter parallèlement à la température hivernale (de $-1{ }^{\circ} \mathrm{C}$ à $+7{ }^{\circ} \mathrm{C}$, Fig. 2), mais la longévité a été meilleure aux faibles températures $\left(\mathrm{de}-1\right.$ à $\left.+5^{\circ} \mathrm{C}\right)$ qu' aux hautes $\left(+7 \mathrm{à}+11^{\circ} \mathrm{C}\right.$; Fig. 2$)$. Le traitement pré-hivernal a eu un effet dramatique sur la valeur adaptative («fitness ») des abeilles. Les abeilles qui avaient pré-hiverné durant $15 \mathrm{j}$ ont eu une meilleure survie et ont vécu plus longtemps que celles qui avaient pré-hiverné durant 45 à $75 \mathrm{j}$ (Fig. 3 ; Tab. IV). Les abeilles qui avaient préhiverné durant $75 \mathrm{j}$ ont perdu environ 4 à $5 \%$ plus de poids que celles qui avaient pré-hiverné durant 45 j (Tab. V). En général les abeilles plus grosses (plus lourdes) étaient plus susceptibles de survivre à l'hiver et vivaient plus longtemps que les petites, mais la taille corporelle n'a eu aucun effet sur la période d'émergence. La pertinence de ces résultats pour les populations sauvages d'O. cornuta est discutée en termes de conditions variables de pré-hivernage et d'hivernage dans le milieu naturel. On discute aussi de l'application de ces résultats pour établir des procédures adéquates de gestion des populations d'O. cornuta utilisées pour la pollinisation des vergers.

Osmia cornuta / température / hivernage / poids corporel / pollinisation / verger

Zusammenfassung - Einfluss von Temperaturverlauf im Vorwinter und im Winter auf Gewichtsverlust, Überlebensrate und Schlupfzeit bei Osmia cornuta (Hymenoptera: Megachilidae). Entpuppte Bienen der univoltinen Solitärbiene Osmia cornuta (Latreille) überwintern in ihren Kokons und benötigen zum Schlupf im Frühjahr Wintertemperaturen gefolgt von einer Erwärmungsperiode. Wir untersuchten Winterverluste, Gewichtsverluste, Schlupfzeit (nach der auf den Winter folgenden Erwärmung) und die Lebensdauer nach dem Schlupf (als Indikator für Vitalität) bei $O$. cornuta. Dazu wurden die Bienen einem unterschiedlichen Temperaturmuster im Vorwinter (Zeit zwischen der Entpuppung und dem Einsatz von winterlichen Temperaturen) und im Winter (Zeit zwischen winterlichen Temperaturen und Erwärmung im Frühjahr) ausgesetzt. Kokons mit adulten Tieren wurden einzeln in Glasbehälter gesetzt und entsprechend den einzelnen Versuchen in Temperaturschränken gelagert. Nach einer Exposition einer Winterdauer von weniger als 30 Tagen schlüpten nur wenige Bienen. 
Ein Maximum an Überlebensrate und Lebensdauer wurde nach einer Überwinterungsdauer von 90150 Tagen erreicht (Abb. 1). Die Schlupfzeit verkürzte sich bei zunehmender Dauer der Überwinterung (Abb. 1) und zunehmenden Überwinterungstemperaturen (Abb. 2). Die Überlebensrate nahm tendenziell mit zunehmenden Wintertemperaturen (von $-1{ }^{\circ} \mathrm{C}$ bis $\left.7{ }^{\circ} \mathrm{C}\right)(\mathrm{Abb} .2) \mathrm{zu}$, aber die Langlebigkeit war höher nach niedrigeren $\left(-1^{\circ} \mathrm{C}\right.$ bis $\left.5^{\circ} \mathrm{C}\right)$ als nach höheren $\left(7^{\circ} \mathrm{C}\right.$ bis $\left.11^{\circ} \mathrm{C}\right)$ Temperaturen (Abb. 2). Die Bedingungen im Vorwinter hatten einen dramatischen Einfluss auf die Fitness der Bienen. Bienen mit einem Vorwinter von 15 Tagen hatten eine höhere Überlebensrate und lebten länger als Bienen mit einem Vorwinter von 45 oder 75 Tagen (Abb. 3, Tab. IV). Bienen mit einem Vorwinter von 75 Tagen verloren 4-5\% mehr an Körpergewicht als Bienen mit einem Vorwinter von 45 Tagen (Tab. V). Im allgemeinen bestand eine größere Wahrscheinlichkeit zum Überleben und auf erhöhte Lebenserwartung bei großen (schwereren) Bienen als bei kleinen, aber die Körpergröße hatte keinen Einfluss auf die Schlupfzeit. Die Bedeutung dieser Ergebnisse für wildlebende $O$. cornuta Populationen wird in Hinsicht auf variable Bedingungen im Vorwinter und Winter unter natürlichen Verhältnissen diskutiert. Die Anwendung dieser Ergebnisse auf gute Haltungsbedingungen im Vorwinter und Winter für $O$. cornuta Populationen, die für die Bestäubung von Obstplantagen eingesetzt werden, wird ebenfalls diskutiert.

\section{Osmia cornuta / Überwinterungstemperatur /} Körpergewicht / Bestäubung von Obstplantagen

\section{REFERENCES}

Allison P.D. (1999) Logistic regression using the SAS system: Theory and application, SAS Institute Inc., Cary, NC.

Asensio E. (1984) Osmia (Osmia) cornuta Latr pollinisateur potentiel des arbres fruitiers en Espagne (Hymenoptera, Megachilidae), in: Proc. V Symp. Int. sur la Pollinisation, 27-30 September 1983, Versailles, pp. 461-465.

Bell R.A. (1989) Manipulation of diapause in the gypsy moth, Lymantria dispar L., by application of KK-42 and precocious chilling of eggs, J. Insect Physiol. 42, 557-563.

Bosch J. (1994a) Improvement of field management of Osmia cornuta (Latreille) (Hymenoptera, Megachilidae), Apidologie 25, 71-83.

Bosch J. (1994b) The nesting behaviour of the mason bee Osmia cornuta (Latr) with special reference to its pollinating potential (Hymenoptera, Megachilidae), Apidologie 25, 84-93.

Bosch J. (1994c) Osmia cornuta Latr. (Hym., Megachilidae) as a potential pollinator in almond orchards. Releasing methods and nest-hole length, J. Appl. Entomol. 117, 151-157.
Bosch J. (1995) Comparison of nesting materials for the orchard pollinator Osmia cornuta (Hymenoptera: Megachilidae), Entomol. Gen. 19, 285-289.

Bosch J., Blas M. (1994a) Foraging behaviour and pollinating efficiency of Osmia cornuta and Apis mellifera on almond (Hymenoptera: Megachilidae, Apidae), Appl. Entomol. Zool. 29, 1-9.

Bosch J., Blas M. (1994b) Effect of over-wintering and incubation temperatures on adult emergence in Osmia cornuta Latr (Hymenoptera, Megachilidae), Apidologie 25, 265-277.

Bosch J., Kemp W.P. (2000) Development and emergence of the orchard pollinator, Osmia lignaria (Hymenoptera: Megachilidae), Environ. Entomol. 29, 8-13.

Bosch J., Kemp W.P. (2001) How to manage the blue orchard bee as an orchard pollinator, Sustainable Agriculture Network, Handbook No. 5, Beltsville.

Bosch J., Kemp W.P. (2002) Developing and establishing bee species as crop pollinators: the example of Osmia spp. (Hymenoptera: Megachilidae) and fruit trees, Bull. Entomol. Res. 92, 3-16.

Bosch J., Kemp W.P. (2003) Effect of wintering duration and temperature on survival and emergence time in males of the orchard pollinator Osmia lignaria (Hymenoptera: Megachilidae), Environ. Entomol. 32, 711-716.

Bosch J., Vicens N. (2002) Body size as an estimator of production costs in a solitary bee, Ecol. Entomol. 27, 129-137.

Bosch J., Kemp W.P., Peterson S.S. (2000) Management of Osmia lignaria (Hymenoptera: Megachilidae) populations for almond pollination: Methods to advance bee emergence, Environ. Entomol. 29, 874-883.

Bosch J., Maeta Y., Rust R.W. (2001) A phylogenetic analysis of nesting behavior in the genus Osmia (Hymenoptera: Megachilidae), Ann. Entomol. Soc. Am. 94, 617-627.

Danks H.V. (1987) Insect dormancy: an ecological perspective, Biological Survey of Canada, Monograph Series No. 1, Ottawa.

Denlinger D.L., Tanaka S. (1999) Diapause, Encycloped. Reprod. 1, 863-872.

Han E.-R., Bauce E. (1997) Effects of early temperature exposure on diapause development of spruce budworm (Lepidoptera: Tortricidae), Environ. Entomol. 26, 307-310.

Han E.-R., Bauce E. (1998) Timing of diapause initiation, metabolic changes and overwintering survival of the spruce budworm, Choristonerua fumiferana, Ecol. Entomol. 23, 160-167.

Hodek I., Hodková M. (1988) Multiple role of temperature during insect diapause: a review, Entomol. Exp. Appl. 49, 153-165.

Hodek I., Honek A. (1996) Ecology of Coccinellidae, Series Entomologica 54, Kluwer Academic Publishers, Dordrecht.

Jacob-Rémacle A. (1990) Étude descriptive des nids d'Osmia cornuta (Latreille, 1805) et Osmia rufa 
(Linné, 1758) (Hymenoptera Apoidea: Megachilidae), Notes Faun. Gembloux 22, 49-64.

Kemp W.P., Bosch J., Dennis B. (2004) Oxygen consumption during the life cycles of the prepupawintering bee Megachile rotundata and the adultwintering bee Osmia lignaria (Hymenoptera: Megachilidae), Ann. Entomol. Soc. Am. 97, 161170 .

Krunic M.D., Brajkovic M.M., Mihajlovic L.S. (1991) Management and utilization of Osmia cornuta Latr. for orchard pollination in Yugoslavia, Acta Hortic. 288, 190-193.

Maccagnani B., Ladurner E., Santi F., Burgio G. (2003) Osmia cornuta (Latreille) (Hymenoptera: Megachlidae) as a pollinator of pear (Pyrus communis L.): fruit- and seed-set, Apidologie 34, 207216.

Maddocks R., Paulus H.F. (1987) Quantitative aspeckte der brutbiologie von Osmia rufa L. und Osmia cornuta Latr. (Hymenoptera, Megachilidae): eine vergleichende Untersuchung zu Mechanismen der konkurrenzminderung zweier nahverwandter bienenarten, Zool. Jb. Syst. 114, 1544.

McLeod D.G.R., Whistlecraft J.W., Harris C.R. (1985) An improved rearing procedure for the carrot rust fly (Diptera: Psilidae) with observations on life history and conditions controlling diapause induction and termination, Can. Entomol. 117, 1017-1024.

Neilson W.T.A. (1962) Effects of temperature on development of overwintering pupae of the apple maggot, Rhagoletis pomonella (Walsh), Can. Entomol. 94, 924-928.

Peters D.S. (1977) Systematik und Zoogeographie der west-paläarktischen Arten von Osmia s str, Monosmia, und Orientosmia, Senckenb. Biol. 58, 287346.

SAS Institute Inc. (1999) SAS/STAT User's guide, Version 8, SAS Institute, Inc. Cary, NC, 3884 p.

Sawyer A.J., Tauber M.J., Tauber C.A., Ruberson J.R. (1993) Gypsy moth (Lepidoptera: Lymantriidae) egg development: a simulation analysis of laboratory and field data, Ecol. Model. 66, 121-155.
Tammaru T., Ruohomäki K., Saloniemi I. (1999) Within-season variability of pupal period in the autumnal moth: a bet-hedging strategy? Ecology 80, 1666-1677.

Taséi J.-N. (1973a) Le comportement de nidification chez Osmia (Osmia) cornuta Latr. et Osmia (Osmia) rufa L. (Hymenoptera: Megachilidae), Apidologie 4, 195-225.

Taséi J.-N. (1973b) Observations sur le dévéloppement chez Osmia cornuta Latr. et Osmia rufa L (Hymenoptera, Megachilidae), Apidologie 4, 295-315.

Tauber M.J., Tauber C.A., Masaki S. (1986) Seasonal adaptations of insects, Oxford University Press, New York.

Tepedino V.J., Torchio P.F. (1982) Phenotype variability in the nesting success among Osmia lignaria propinqua females in a glasshouse environment (Hymenoptera: Megachilidae), Ecol. Entomol. 7, 453-462.

Torchio P.F. (1985) Field experiments with the pollinator species, Osmia lignaria propinqua Cresson in apple orchards: V, (1979-1980), methods of introducing bees, nesting success, seed counts, fruit yields (Hymenoptera: Megachilidae), J. Kans. Entomol. Soc. 58, 448-464.

Torchio P.F., Asensio E., Thorp R.W. (1987) Introduction of the European bee, Osmia cornuta, into California Almond Orchards (Hymenoptera: Megachilidae), Environ. Entomol. 16, 664-667.

Vicens N., Bosch J. (2000a) Weather-dependent pollinator activity in an apple orchard, with special reference to Osmia cornuta and Apis mellifera (Hymenoptera: Megachilidae and Apidae), Environ. Entomol. 29, 413-420.

Vicens N., Bosch J. (2000b) Pollinating efficacy of Osmia cornuta and Apis mellifera (Hymenoptera: Megachilidae, Apidae) on "Red Delicious" apple, Environ. Entomol. 29, 235-240.

Wang T., Laing J.E. (1989) Diapause termination and morphogenesis of Holcothorax testaceipes Ratzeburg (Hymenoptera: Encyrtidae), an introduced parasitoid of the spotted tentiform leafminer, Phyllonorycter blancardella (F.) (Lepidoptera: Gracillariidae), Can. Entomol. 121, 65-74. 